\title{
25 Years at the Margins- The Global Politics of HIV/AIDS
}

Today, more than 40 million people are living with HIV/AIDS, and well over 20 million more have died since the first case was diagnosed in 1981. When we include families and loved ones in the raw demographics, HIV/AIDS has touched a population at least equal to that of the United States. This collection of essays examines the complexity of the mobilization against HIV/AIDS, from the perspective of social action on one hand and the state on the other.

We thank Andrea Densham, Jeff Edwards, and the anonymous reviewers for their dedication and critical engagement. We also extend our gratitude to those AIDS activists and their friends and loved ones whose open participation makes research of this kind possible.

\section{Introduction: Politics as a Cause and Consequence of the AIDS Pandemic}

\author{
Andrea Densham
}

( n June 5, 1981, an obscure public health bulletin published by the Centers for Disease Control in Atlanta first reported that five young men- "all active homosexuals" - had contracted a very rare pneumonia, the cause of which was entirely unknown. The report went on to note that two of the five men had died and that the other three were very ill. These were the first five reported cases in the United States of a deadly disease soon to be known around the world as acquired immune deficiency syndrome (AIDS). The public health and scientific communities have since learned that cases of human immunodeficiency virus (HIV) were also emerging simultaneously in Africa, Europe, and other parts of North America, but the 1981 Morbidity and Mortality Weekly Report, the first scientific documentation of HIV, marked the beginning of a global public health crisis. And it did so in

Andrea Densham, Principle of Densham Consulting in Chicago, is a health policy advocate and former health policymaker(a.densham@gmail.com). She haswritten on social movements and health policy as they relate to LGBT health, HIV, and breast cancer. ways that would shape the form and content of political discourse and dissent for decades to come. ${ }^{1}$

As we commemorate World AIDS Day on December 1 and the first twenty-five years of AIDS in 2006, our communities, our nations, and we ourselves continue to struggle with the devastating impact of this virus. The Joint United Nations Programme on HIV/AIDS (UNAIDS) notes that, in " 25 years, HIV has spread relentlessly from a few widely scattered 'hot spots' to virtually every country in the world, infecting 65 million people and killing 25 million." ${ }^{2}$ Unlike many previous epidemics that have progressed from transmission to containment or eradication, this epidemic is still spreading. So long after its first appearance, the pandemic remains in the expansion stage throughout much of Asia and Central Europe, while it continues to grow in already impacted regions. Indeed, this is an epidemic for which containment has been elusive. For those with access to advanced treatment and medications, HIV has been converted from a terminal diagnosis to a manageable chronic disease, and for those with access to education and condoms, AIDS is largely preventable. For those without such access, including millions in the global South as well as substantial segments of the global North, AIDS remains highly contagious and deadly. 
HIV is a powerful virus that eats at the fundamental components of the body's infrastructure. It identifies the body's weaknesses and works to destroy us from within. HIV has the same relationship to society. Inadequate societal and political responses to HIV have caused immense human misery, evident not only in loss of life, but also in the impact of the disease on social structures, economic potential, and political stability. This impact is most devastating to those who inhabit the margins of domestic and global society. It is here, where marginalization and neglect intersect and politics fails to assist those often most in need, that HIV has flourished.

It is at this juncture that Perspectives on Politics considers the first quarter century of HIV/AIDS: the politics of failure and opportunity, from the stigmatization and mobilization of individuals and communities, to the avoidance or engagement of states. This symposium represents the first time an American Political Science Associationaffiliated journal has allocated adequate space to examine the complexity of AIDS as a challenge both to politics and to scholarship. These are the first articles presenting empirical research or theoretical claims regarding the pandemic since Patricia Siplon (who contributes here, as well) discussed the dilemmas of research in 1999, and before that Ken Sherrill, Carolyn Somerville, and Robert Bailey chastised the discipline for "downplaying AIDS" on the pages of PS: Political Science and Politics in December 1992. ${ }^{3}$

\section{Political Science and the Global Impact of HIV}

The response to HIV has profoundly changed political, social, and economic structures around the world. The changes are both global in their influence and specific in their national and community impact. Societal responses to HIV transform every aspect of politics-from global economies and international security to the basic structures of power and dynamics of mobilization among states and between states and citizens. HIV has required communities, governments, and nations across the world to struggle with the most basic elements of society: What is the role of government and state power vis-à-vis citizens' health? What role do citizens play in shaping public policy as it relates to drug approval or disease prevention? To what extent can a nation-state dictate to multinational corporations the parameters of intellectual property rights? How do neoliberal and human rights regimes respond differently to health crises? And when does the transmission of a virus become a matter of national security?

Despite this interrogation of political institutions and the concomitant challenges to political and social relationships, the discipline of political science has been shockingly silent with regard to HIV and its impacts over the past 25 years. Tragically, it is in just such situations- when we most need the best minds to apply the sharpest analytic skills to one of the most complex global crisesthat the discipline has failed. Over the past 25 years, we have needed to know what global development strategies have worked, what political interventions have failed, and how community members can reshape political and economic regimes. Community leaders, public officials, and the private sector look to scholars to take the time to apply rigorous social sciences methods to present-day problems and provide insight about how best to move forwardbut for the most part, they have had to look elsewhere.

Still, even in the face of institutional resistance, a handful of political scientists have applied their analytic skills to investigate this global epidemic. ${ }^{4}$ Cathy Cohen's work, for example, presents a provocative approach to the multilayered nature of marginalization and the responses to HIV/AIDS in the African American community. Cohen's work is not only analytically rigorous and relevant, but it also impacts upon day-to-day actions of communities and leaders across the country while continuing to shape political discourse nationally. Taking a different approach, Evan Lieberman has turned to the relationship of state institutions and civil society in the response to AIDS. ${ }^{6}$ Others have taken their passion from the streets as activists and applied it to their scholarship. For instance, Deborah Gould's work on AIDS activism in the United States combats disciplinary orthodoxy to explore a social movement she helped to build. ${ }^{7}$ Her work has unleashed social science scholarship to investigate the impact of emotions on political participation and demanded that the field recognize the profound changes occurring because of the AIDS epidemic. Patricia Siplon has examined policy responses to HIV/AIDS in the United States and the politics of access to treatment globally, ${ }^{8}$ themes already taken up by other contributors to this symposium, as well. ${ }^{9}$

These scholars have provided insights that contexutalize the impact of HIV on the ground, illuminating local realities while providing critical analyses that can then be applied to improve future actions. Despite these efforts, such scholarship is far too rare and far too undervalued when compared to the profound shifts in our political landscape due to the AIDS epidemic and to its potential to advance our knowledge about, at the very least, political development, state-society relations, globalization, inequality, social movements, transnational activism, international organizations, and race, gender, and sexuality. As the discipline examines its foundations and its connection to the political world, such scholarship embodies a humanistic turn, keeping one foot in the political both out of a sense of responsibility and as an approach to research. But we are in desperate need of a variety of analytical tools as we attempt to fathom the political causes and consequences of a pandemic that has already killed 25 million people and at this moment threatens the lives of 65 million others and the well-being of their families and communities. 


\section{Analytic Tools for Global Examinations}

The distribution of HIV allows us to examine the political reaction to the same medical condition of a variety of nation-states and affected communities, over a finite period of time. Bringing together political scientists and activists working on and with HIV/AIDS in varied contexts, this symposium offers the reader a collection of essays bridging the divergent roles of states and other power-holders, methods and dimensions of marginalization, and tools employed by those communities hardest hit by AIDS as they mobilize to effect political and social change.

These articles provide a critical comparative investigation that highlights the power of different interventions across citizenries and nation states. Each author takes on a distinct political and sequential context and features a specific analytical lens for examining both the local and the global of the pandemic. But rather than claim the last word, we aim to foster more such investigations of other regions and communities, informed by a wider array of perspectives and priorities. In their brief analyses, our authors each address state responsibility and societal mobilization, but they reach different conclusions and highlight different aspects of politics. This divergence reflects not only different perspectives, but also a tension inherent in describing HIV/AIDS simultaneously as a series of community epidemics and as a global pandemic. Moreover, we cannot cover every context here-China, India, and so many other critically important cases, for instance, are beyond our scope.

Given limited space, we have decided to highlight responses outside the United States even if references to the varied responses to HIV in the United States lurk often in the background. Nevertheless, it is important to note that the United States presents a useful point of departure for examining the HIV epidemic over the past 25 years. It is clear today that the initial American reaction to AIDS was inexcusably tardy and entirely insufficient. We also know that the federal government, in some sectors blinded by prejudice and deafened by ideology, was at times frozen into inaction as its citizens demanded help to stop the spread of this deadly virus, and at other times pursued policies denounced by public health officials and the communities affected. ${ }^{10}$ In response to neglect and attack, gay men facing sickness and death partnered with lesbians and straight allies to marshal lessons learned from social movements in previous decades. AIDS activists made this disease a core part of American public discourse and themselves a powerful new force in American politics. ${ }^{11}$

Indeed, AIDS activism initiated the development of single-issue health movements in United States-first for breast cancer, then for a diverse assortment of other significant health conditions on the basis of which activists clamor for a share of our nation's health care dollars. Today, health appropriations and budget processes at the federal and states levels have become battlefields on which interest groups wrestle over disease specific allocations and ideological policy implications (for example, the actual practice as well as larger significance of domestic and international spending on condoms or reproductive health). In AIDS politics, an entire industry of disease-specific health lobbyists and advocates has grown out of the early work of activists in the 1980s, at the state and local as well as federal levels. ${ }^{12}$ Indeed, current assumptions of bureaucratic transparency are a direct result of the political influence asserted by AIDS activists in the early days of this health crisis. Equally as important, attention to international aid packages and their specific levels of support for AIDS prevention and treatment programs has become a regular item on the front pages of American newspapers.

As the United States was an early "hotspot" of the AIDS epidemic, its responses informed governments and advocates in other nations, as well. Some learned from the mistakes in the United States and others creatively adapted successes here to the realities on the ground in their home countries. This conscientious adaptation of international successes has happened less often in the other direction. Even here, though, a handful of activists, scientists, and public health researchers have taken the time to learn about successful policy interventions and mobilization strategies in countries like Brazil and Uganda in hopes that comparable strategies could be similarly effective in the United States. For example, participants in various international AIDS training programs have worked in teams to develop cross-national best practices. Many American team members have noted the wealth of knowledge they have collected working with colleagues from other nations that they are now applying on the ground in the U.S. ${ }^{13}$

The past quarter-century of HIV/AIDS provides a unique lens through which to examine the responses of citizens, governments, and the private sector to this nowomnipresent disease. It is in examining patterns of marginalization, mobilization, impact on and action of global markets, engagement of states, and the role of science and medicine that we can partake in critical empirical analysis and, perhaps more importantly, begin to illuminate paths of success and failure and learn how states and societies respond to new challenges in an era of transnational activism, international institution-building, and globalization.

\section{Symposium Overview: Making Sense of Mobilization around HIV/AIDS}

The HIV pandemic poses fundamental questions of the structure of our political, social, and economic institutions. What is the role of the state in the health of its citizens? What is the role of nongovernmental organizations in reshaping state policy? How has the global economy molded the tools available to marginalized communities in their efforts to effect change? In what ways do transnational 
corporations encourage unique multinational alliances? In what contexts have fear and confusion stymied proactive efforts to cope with HIV/AIDS? The following papers engage these questions head on, approaching HIV/AIDS as a complex and dynamic challenge for social scientists as well as for policymakers and activists. We start with the state: what governments can and should do, and when and why they fail to act. Even optimal state policies are inadequate alone, however, as we discover when we turn our gaze to the potential of civil society and when we consider the limits of states' authority and repertoires. Taking the investigation full circle, we take the state out of the picture, exploring the externalities of government abnegation or avoidance. All these approaches to understanding HIV/AIDS consider issues of mobilization and marginalization, but from global and local, state and grassroots, activist and beneficiary perspectivesand these are only a few of the different ways of approaching the social science of HIV/AIDS.

While recent commentaries have been rightfully critical of the persistent inaction of some nonwestern states, it is important to recall that the initial response of industrialized democracies was poor at best. Michael Bosia's contribution, "Written in Blood: AIDS Prevention and the Politics of Failure in France," illustrates the devastating impact of government policy based on false assumptions and shortsighted interpretations of state interests at the dawn of neoliberal globalization. Bosia examines the French response to the growing HIV epidemic in the early 1980s, when both the epidemiology of the disease and activist mobilization were conditioned by decisions made by states. Like most other countries, France failed to act quickly to secure the safety of the nation's blood supply. In examining the capacity perceptions of the French government in the face of a neoliberal imperatives and misconceptions regarding HIV, Bosia notes that the government understood HIV to be a disease of American homosexuals rather than a blood-borne virus that would attack any host it had the opportunity to inhabit. In addition, "rationalized" decisionmaking privileged fiscal reform and market dynamics over the public's health and security, at a time when state action in response to AIDS was especially critical, in ways that foreshadowed the neoliberal challenge to AIDS today. Bosia's analysis of finger pointing and denial of responsibility illuminates an unfortunately widespread and prevalent assumption that officials win when no one takes responsibility.

In "Roadblocks on the Road to Treatment: Lessons from Barbados and Brazil," Patricia Siplon and Jamila Headley provide a different lens to examine state action: through the importance of civil societal mobilization. While many countries within the developing world struggle with the delivery of affordable antiretroviral medications, the governments of Brazil and Barbados have both implemented ambitious programs to provide universal treatment access. ${ }^{14}$ Yet their approaches to treatment have diverged signifi- cantly, reflecting striking sociopolitical differences, particularly in terms of the sources of political will for the programs and the origins and costs of the medications used. This essay suggests that mobilization in favor of treatment access within civil society, and especially among people living with HIV/AIDS themselves, provides a significant spur to state action, as officials negotiate with both international institutions and the global pharmaceutical industry. States may mobilize even in the absence of such a catalyst, but their responses may be less effective and sustainable. In addition, this contribution examines a complicated reciprocal relationship between prevention interventions, access to affordable health care, stigma related to disease, rates of voluntary testing within target populations, and attaining the most basic public health goalreducing mortality.

In "Framing AIDS Mobilization and Human Rights in Post-apartheid South Africa," Krista Johnson likewise homes in on the nexus between state and civil society, but from a different direction, illuminating the ways activists frame their messages and tailor approaches to contest state as well as business interests. The lack of a unified national response to AIDS in countries across the globe has often, as the UNAIDS notes, "been a source of tension between government and civil society." ${ }^{15}$ The concurrent timing of South Africa's emerging AIDS epidemic and installation of a new post-apartheid national constitution in the early 1990 s provides Johnson the empirical data to investigate and compare the deployment of constitutional rights as part of civil engagement, state action, and stakeholders' strategies. In her study of mobilizations around access to treatment, Johnson examines the ways activists have adjusted a civil rights frame to become inclusive of the broad socioeconomic and human rights guaranteed by the post-apartheid constitution. But this frame is contested, with both multinationals and activists using the courts and the language of rights to make their claims. This paper reveals how in a country such as South Africa, where prevalence rates exceed 20 percent of the population, a rights-based approach to AIDS has fostered an adversarial relationship between government and civil society and hindered an effective response to the pandemic.

This symposium concludes with Meredith Weiss's "Rejection as Freedom? HIV/AIDS Organizations and Identity," which explores mobilization within civil society in the absence of state engagement and the possibilities thus enabled for fostering new, potentially political identities. She focuses on Singapore and Malaysia, both states with highly controlled civil societies. Even under semidemocratic regimes, the government's reluctance to deal with the communities most affected by HIV/AIDS—-sex workers, gay men, and others-may render HIV/AIDS organizations comparatively free spaces in civil society: places outside the gaze of the state (even if not immune to societal cleavages and animosities) in which comarginals 
may congregate, become aware of their shared structural subordination, find international allies and sponsors, develop leadership and expertise, and disrupt assumptions of state hegemony. In the cases in question, as in the United States and elsewhere, mobilization around HIV/AIDS has helped to foster new identities and networks, gradually destigmatizing key dimensions of difference. The question remains whether activists may mobilize in this "free space" beyond engagement for survival and begin to transform the relationship between civil society and government. Weiss points to the need for further investigations into the impact that delimited means of condoned public dissent may have on the tools employed by marginalized communities and their relative policy efficacy.

This symposium is but the first step towards grasping the diverse and lasting impact that HIV/AIDS has had, not only on the health and wellbeing of so many world citizens, but also on relationships between states and citizens and among corporations, governments, and civil societies. HIV/AIDS has brought into relief the immense power that can be harnessed by citizens demanding a voice and equal status in civil society, as well as by states demanding concessions from dauntingly powerful international interests. We hope this collection succeeds in stimulating further examination into and scholarship on how mobilization around HIV/AIDS in its first 25 years has changed our practice and understanding of advocacy, activism, and policy change.

\section{Notes}

1 The early struggle of scientists and public officials to understand the relationship between the identity of those impacted and the etiology of the disease was apparent in an editorial note in this very first report: "Pneumocystis pneumonia in the United States is almost exclusively limited to severely immunosuppressed patients ... The occurrence of pneumocystosis in these 5 previously healthy individuals without a clinically apparent underlying immunodeficiency is unusual. The fact that these patients were all homosexuals suggests an association between some aspect of homosexual lifestyle or disease acquired through sexual contact and Pneumocystis pneumonia in this population" (CDC 1981, 250-2).

2 UNAIDS/WHO 2006, 4.

3 Siplon 1999; Sherrill, Somerville, and Bailey 1992.

4 These scholars include Juan Battle, Hector Carrillo, Rafael Diaz, Amy Patterson, and Jeremy Youde.

5 Cohen 1999.

6 Lieberman (forthcoming).

7 Gould 2001, 135-57; 2006.

8 Siplon 2002; Smith and Siplon 2006.

9 For instance, Bosia 2005; Johnson 2004.
10 A telling example: federal dollars still cannot be used to support prevention programs that "promote" homosexuality.

11 Epstein 1996.

12 For instance, Edwards 2000.

13 A prime example of this commitment is the work of the Academy for Education Development. In its description of its U.S.-based work on HIV, the organization describes itself as "a leader in applying lessons learned in fighting the epidemic internationally to HIV/ AIDS prevention efforts in the United States" (www.aed.org/HIVAIDS). Another example is the AIDS Care Team at the Enhancing Care Initiative housed within the Harvard School of Public Health. This group has developed lessons learned and tools that apply cross-nationally and are used by HIV policy makers in the United States (www.eci.harvard.edu).

14 Siplon and Headley are very right to construct their analysis around universal treatment access rather than antiretrovirals (ARVs) alone. There is no doubt that without the advent of ARVs, many more people would have died across the world. However, ARV treatment is complicated, can produce serious side effects, and requires regular access to health care. Given these conditions, universal treatment access is the most appropriate indicator of responsible state action.

15 UNAIDS/WHO 2004, 2.

\section{References}

Bosia, Michael. 2005. Assassin! AIDS and neoliberal reform in France. New Political Science 27 (3): 291-308.

Centers for Disease Control and Prevention. 1981. Pneumocystis Pneumonia-Los Angeles. Morbidity and Mortality Weekly Report 30: 250-2.

Central Intelligence Agency. 2005. The World Factbook. Washington, DC: Central Intelligence Agency.

Cohen, Cathy. 1999. The Boundaries of Blackness: AIDS and the Breakdown of Black Politics. Chicago: University of Chicago Press.

Edwards, Jeffrey. 2000. AIDS, race, and the rise and decline of a militant oppositional lesbian and gay politics in the US. New Political Science 22 (4): 485-506.

Enhancing Care Initiative. 2004. "Collaborating to Improve HIV/AIDS Care and Treatment in ResourceScare Settings: How to Form and Sustain Effective AIDS Care Teams." Cambridge: Harvard School of Public Health.

Epstein, Steven. 1996. Impure Science: AIDS, Activism, and the Politics of Knowledge. Berkeley: University of California Press.

Fee, Elizabeth, and Daniel M. Fox, ed. 1988. AIDS: The Burdens of History. Berkeley: University of California Press. 
Gauri, Varun, and Evan Lieberman. N.d. Institutions, social boundaries, and epidemics: Explaining government AIDS policies in Brazil and South Africa. Available online at http://www.ssc.upenn.edu/polisci/ programs/comparative/LiebermanPaper.pdf.

Gould, Deborah. 2001. Rock the boat, don't rock the boat, baby: Ambivalence and the emergence of militant AIDS activism. In Passionate Politics: Emotions and Social Movements, ed. Jeff Goodwin, James Jasper, and Francesca Polletta. Chicago: University of Chicago Press.

- 2006. The shame of gay pride in early AIDS activism. In Gay Shame, ed. Valerie Traub and David Halperin. Chicago: University of Chicago Press.

Johnson, Krista. 2004. The politics of AIDS policy development and implementation in postapartheid South Africa. Africa Today 51 (2): 107-28.

Lieberman, Evan. Forthcoming. "Politics in Really Hard Times: Ethnicity, Public Goods, and State Responses to HIV/AIDS in Sub-Saharan Africa." In manuscript. McLaughlin, Loretta. 1989. AIDS: An overview. In The AIDS Epidemic: Private Rights and Public Interest, ed. Padraig O'Malley. Boston: Beacon Press.
Sherrill, Kenneth S., Carolyn M. Somerville, and Robert W. Bailey. 1992. What Political Science is missing by not studying AIDS. PS: Political Science and Politics 25 (4): 688-93.

Siplon, Trish. 2002. AIDS and the Policy Struggle in the U.S. Washington, D.C.: Georgetown University Press.

1999. A brief history of the political science of AIDS activism. PS: Political Science and Politics 32 (3): 578-81.

Smith, Raymond, and Trish Siplon. 2006. Drugs into Bodies: Global AIDS Treatment Activism. Westport, CT: Praeger Publishers.

Summers, Todd, and Jennifer Kates. 2004. Trends in U.S. Government Funding for HIVIAIDS_Fiscal Years 1981 to 2004. Menlo Park: The Henry J. Kaiser Family Foundation.

UNAIDS/WHO. 2006. 2006 Report on the Global AIDS Epidemic. Geneva: Joint United Nations Programme on HIV/AIDS and World Health Organization. 